\title{
Cardiac Tropism of Borrelia burgdorferi
}

\section{An Autopsy Study of Sudden Cardiac Death Associated with Lyme Carditis}

Atis Muehlenbachs, ${ }^{*}$ Brigid C. Bollweg, ${ }^{*}$ Thadeus J. Schulz, ${ }^{\dagger}$ Joseph D. Forrester, ${ }^{\ddagger}$ Marlene DeLeon Carnes, ${ }^{*}$ Claudia Molins, Gregory S. Ray, ${ }^{\dagger}$ Peter M. Cummings, ${ }^{\S}$ Jana M. Ritter, ${ }^{*}$ Dianna M. Blau, ${ }^{*}$ Thomas A. Andrew, ${ }^{\natural}$ Margaret Prial, Dianna L. Ng, Joseph A. Prahlow, ${ }^{* * \dagger \dagger}$ Jeanine H. Sanders, ${ }^{*}$ Wun Ju Shieh, ${ }^{*}$ Christopher D. Paddock, ${ }^{\star \star}$ Martin E. Schriefer,, Paul Mead $^{\ddagger}$ and Sherif R. Zaki*

\begin{abstract}
From the Infectious Diseases Pathology Branch,* Division of High Consequence Pathogens and Pathology, Centers for Disease Control and Prevention, Atlanta, Georgia; CryoLife, Inc, ${ }^{\dagger}$ Kennesaw, Georgia; the Bacterial Diseases Branch, ${ }^{\ddagger}$ Division of Vector Borne Infectious Diseases, Centers for Disease Control and Prevention, Ft. Collins, Colorado; the Office of the Chief Medical Examiner, ${ }^{\S}$ Boston, Massachusetts; the Office of the Chief Medical Examiner, Concord, New Hampshire; the Office of the Medical Examiner, "Goshen, New York; The Medical Foundation, ** South Bend, Indiana; the Indiana University School of Medicine-South Bend, ${ }^{\dagger \dagger}$ South Bend, Indiana; and the Rickettsial Zoonotic Diseases Branch, ${ }^{\ddagger \ddagger}$ Division of Vector Borne Infectious Diseases, Atlanta, Georgia
\end{abstract}

\author{
Accepted for publication \\ December 15, 2015. \\ Address correspondence to Atis \\ Muehlenbachs, M.D., Ph.D., \\ Infectious Diseases Pathology \\ Branch, CDC, 1600 Clifton Rd. \\ NE, MS G32, Atlanta, GA \\ 30329-4018. E-mail: vkd6@ \\ cdc.gov.
}

\begin{abstract}
Fatal Lyme carditis caused by the spirochete Borrelia burgdorferi rarely is identified. Here, we describe the pathologic, immunohistochemical, and molecular findings of five case patients. These sudden cardiac deaths associated with Lyme carditis occurred from late summer to fall, ages ranged from young adult to late $40 \mathrm{~s}$, and four patients were men. Autopsy tissue samples were evaluated by light microscopy, Warthin-Starry stain, immunohistochemistry, and PCR for B. burgdorferi, and immunohistochemistry for complement components C4d and C9, CD3, CD79a, and decorin. Post-mortem blood was tested by serology. Interstitial lymphocytic pancarditis in a relatively characteristic road map distribution was present in all cases. Cardiomyocyte necrosis was minimal, T cells outnumbered B cells, plasma cells were prominent, and mild fibrosis was present. Spirochetes in the cardiac interstitium associated with collagen fibers and co-localized with decorin. Rare spirochetes were seen in the leptomeninges of two cases by immunohistochemistry. Spirochetes were not seen in other organs examined, and joint tissue was not available for evaluation. Although rare, sudden cardiac death caused by Lyme disease might be an underrecognized entity and is characterized by pancarditis and marked tropism of spirochetes for cardiac tissues. (Am J Pathol 2016, 186: 1195-1205; http://dx.doi.org/10.1016/j.ajpath.2015.12.027)
\end{abstract}

Lyme disease is caused by the spirochete Borrelia burgdorferi in North America and transmitted by certain species of Ixodes ticks. Approximately 30,000 cases are reported annually in the United States, but the actual number may be 10-fold higher. ${ }^{1}$ Other Borrelia species in the B. burgdorferi sensu lato complex, including Borrelia afzelii and Borrelia garinii, cause Lyme disease in Europe. Clinical symptoms are largely dermatologic, neurologic, and musculoskeletal. In the United States, cardiovascular symptoms occur in approximately $1.1 \%$ of reported cases, ${ }^{2}$ can manifest as conduction block, ${ }^{3,4}$ and, when recognized, usually resolve with appropriate antibiotics. ${ }^{5}$ Fatal myocarditis is rare, with

\footnotetext{
Supported by the Centers for Disease Control and Prevention.

The findings and conclusions herein are those of the authors and do not necessarily represent the official position of the Centers for Disease Control and Prevention.

Disclosures: T.J.S. and G.S.R. are employed by, and have stock options in CryoLife, Inc.

Current address of J.D.F., Division of General Surgery, Stanford University, Palo Alto, CA; of D.L.N., Departments of Pathology and Laboratory Medicine, University of California at San Francisco, San Francisco, CA; of J.A.P., Homer Stryker MD School of Medicine, Western Michigan University, Kalamazoo, MI.
} 
only four cases reported before 2013 in the United States ${ }^{6-8}$ and Europe, ${ }^{9}$ including three cases with detailed pathology findings. ${ }^{6-8}$ In 2013, the CDC reported three additional cases of fatal carditis associated with Lyme disease. ${ }^{10}$

The most frequently described pathologic findings in Lyme disease correlate with the clinical stages of disease. ${ }^{11,12}$ In early localized disease ( 3 to 30 days after tick bite), skin biopsy specimens of erythema migrans show lymphohistiocytic perivascular dermatitis, whereas in latestage disease (months to years after tick bite), synovial biopsy specimens for arthritis classically show synovium with villous proliferation, lymphoplasmacytic infiltrates, and microangiopathic change. ${ }^{13}$ Lyme carditis occurs most frequently during early disseminated Lyme disease, generally days to weeks after tick bite. Endomyocardial biopsy specimens and autopsy findings show edema, subendocardial infiltrates (on biopsy specimen), pancarditis (on autopsy) with perivascular interstitial infiltrates, increased collagen deposition, and limited cardiomyocyte necrosis. ${ }^{7,8,14,15}$ Largely European studies of central nervous system pathology during early disseminated to late-stage disease have described brain and spinal cord meningeal and perivascular infiltrates, gliosis, microglial activation and glial nodules, ${ }^{16}$ involvement of cranial nerves ${ }^{17}$ in addition to peripheral nerve infiltrates, and axonal degeneration. ${ }^{18}$ Other fatal complications reported include a case of acute respiratory distress syndrome, ${ }^{19}$ and neonatal death after transplacental transmission. ${ }^{20,21}$

By histopathology, spirochetes have been reported in skin, ${ }^{22-24}$ synovium, ${ }^{13}$ ligament, ${ }^{25}$ spleen, ${ }^{26,27}$ leptomeninges, ${ }^{17}$ and heart ${ }^{7,15,28}$ using silver stains. However, spirochetes often are not visualized, as documented in confirmed cases of neuroborreliosis, ${ }^{16}$ fatal myocarditis, ${ }^{6,8}$ and lymphocytoma cutis, ${ }^{29}$ likely because of low numbers of spirochetes and high background seen in conventional silver stains. PCR can identify (or detect) B. burgdorferi DNA in tissue, ${ }^{8,29}$ and, more recently, immunohistochemistry (IHC) has been used to show borrelial antigens in clinical specimens ${ }^{30}$ and in experimental models. ${ }^{31}$

B. burgdorferi possesses numerous adhesins that bind host extracellular matrix molecules, including glycosaminoglycans, fibronectin, collagen, and the small proteoglycan decorin, ${ }^{32}$ which mediate tissue tropism, pathogenicity, and immune invasion. In experimentally infected mice, $B$. burgdorferi binding to decorin has been implicated in spirochete cardiac tissue tropism. ${ }^{31,33}$

Here, we report the pathologic, immunohistochemical, molecular, and serologic findings of five cases of sudden cardiac death associated with Lyme disease and show marked tropism of spirochetes for heart tissue, providing insight into the pathogenesis of Lyme myocarditis. Partial data on three of the five patients have been published previously ${ }^{10}$; together, these and additional data are reported here and provide a broader description of a rare disease.

\section{Materials and Methods}

\section{Patient Selection}

Autopsy specimens were submitted to the CDC Infectious Diseases Pathology Branch and Bacterial Diseases Branch Laboratories in 2013 to 2014 by medical examiners and state public health laboratories. All cases with laboratory evidence of $B$. burgdorferi infection were included. A median of 3 (range, 1 to 5) cardiac specimens were submitted per case. Other tissues were evaluated as available and are described later.

Autopsy tissues from patients were submitted to the CDC as part of a public health investigation, and did not require review by an institutional review board. In an effort to maintain family confidentiality, data are presented in summary form and specific ages are not provided.

\section{Histochemistry}

Hematoxylin and eosin, Warthin-Starry (WS), and trichrome stains were performed according to standard protocols using Leica ST5020 multistainer (Leica, Buffalo Grove, IL), Dako Artisan Link autostainers (Dako, Carpinteria, CA), and manual methods, respectively. Slides for the WS stain were cut at $5-\mu \mathrm{m}$ thickness to maximize detection of spirochetes.

\section{Immunohistochemistry}

IHC was performed using a polymer-based indirect immunoalkaline phosphatase detection system with a fast red chromogen for the colorimetric detection of an antibody/polymer complex (Biocare Medical, Concord, CA). B. burgdorferi IHC was performed using rabbit polyclonal antibody (immunized against a whole-cell preparation) (ab34970; Abcam, Cambridge, MA), used at a 1:1000 dilution with proteinase $\mathrm{K}$ pretreatment. ${ }^{31}$ Internal validation data showed that this assay cross-reacts with Borrelia hermsii and Treponema pallidum, but does not detect Leptospira species (data not shown). A mouse monoclonal antibody against $B$. burgdorferi flagellin (clone H9724), used at a 1:2000 dilution (gift from Barbara Johnson, Division of Vector Borne Diseases, CDC) was used for confirmation (data not shown). To evaluate for cardiomyocyte injury, IHC for complement components $\mathrm{C} 4 \mathrm{~d}$ and C9 was performed as previously described. ${ }^{34,35}$ Mouse monoclonal antibodies against CD3 (M7254; Dako) and CD79a (sc20064; Santa Cruz Biotechnology, Dallas, TX) were used at 1:100 and 1:500 dilutions, respectively. Rabbit polyclonal antidecorin (immunized against a recombinant protein epitope tag) (HPA003315; Sigma Aldrich, St. Louis, MO) was used at a 1:100 dilution. ${ }^{36}$ To evaluate for co-infections, IHC for Heartland virus was performed as previously described. ${ }^{37} \mathrm{IHC}$ for Powassan virus used hyperimmune mouse ascitic fluid (courtesy of Pierre Rollin, CDC), which is known to detect Powassan virus antigens in formalin-fixed, paraffin-embedded (FFPE) human tissues at a 1:1000 dilution. IHC for Anaplasma 
phagocytophilum used horse polyclonal antibody (gift from Richard E. Cortsvet, Louisiana State University), which is known to detect A. phagocytophilum in FFPE human tissues at a 1:1000 dilution.

\section{PCR}

DNA were extracted from FFPE tissues as previously described using the QIAamp DNA Mini Kit (Qiagen, Valencia, CA). ${ }^{38}$ DNA was extracted from whole blood using the QIAamp DNA Mini Kit (Qiagen) following the manufacturer's instructions. Primers and probes targeting outer surface protein $\mathrm{A}^{39}{ }^{39}$ flagellin, ${ }^{40}$ and plasminogen binding protein $^{41}$ were modified slightly and used for real-time PCR. PCR for outer surface protein A was performed in $25-\mu \mathrm{L}$ volumes with $5 \mu \mathrm{L}$ DNA extract using the QuantiTect Multiplex PCR Kit (Qiagen), and run on the Mx3005P QPCR System (Agilent, Santa Clara, CA) with cycling conditions of $95^{\circ} \mathrm{C}$ for 15 minutes, 45 cycles of $94^{\circ} \mathrm{C}$ for 1 minute, and $60^{\circ} \mathrm{C}$ for 1 minute. Positive controls included FFPE blocks containing cell culture isolates of $B$. burgdorferi (courtesy of Barbara Johnson, Division of Vector Borne Diseases, CDC). Samples were considered positive when the threshold cycle value was $\leq 40$. PCR for flagellin and plasminogen binding protein was performed in $20-\mu \mathrm{L}$ volumes with 5 to $10 \mu \mathrm{L}$ of DNA extract using TaqMan Fast Universal PCR Master Mix (Life Technology, Grand Island, NY) and run on the AB 7500 FAST Dx Real-Time PCR instrument (Applied Biosystems, Grand Island, NY) with cycling conditions of $95^{\circ} \mathrm{C}$ for 20 seconds, 45 cycles of $95^{\circ} \mathrm{C}$ for 3 seconds, and $60^{\circ} \mathrm{C}$ for 30 seconds. Samples were considered positive if their threshold cycle value was $\leq 40$ and less than the threshold cycle value of the positive control. PCR for Babesia microti was performed as previously described ${ }^{42}$ to evaluate for co-infection. ${ }^{7}$

\section{Serology}

At the CDC, all serologic tests were performed using patient sera and following the manufacturer's instructions. Two enzyme immunoassays were used: a whole-cell sonicate enzyme immunoassay [Vitek Immunodiagnostic Assay System (VIDAS) Lyme IgM and IgG Polyvalent Assay, bioMérieux, Inc., Durham, NC] and the C6 B. burgdorferi (Lyme) enzyme immunoassay (Immunetics, Boston, MA). IgM and IgG Western Blots (WBs) (MarDx Diagnostics, Inc., Carlsbad, CA) also were run on all patient sera. The immunoblotting results were interpreted according to the guidelines proposed by the $\mathrm{CDC},{ }^{43}$ in which 2 of the 3 bands and 5 of the 10 bands are required for positive $\operatorname{IgM}$ and $\operatorname{IgG} \mathrm{WBs}$, respectively.

\section{Results}

\section{Demographic and Clinical Data}

Summary data are presented in Table 1. Briefly, ages ranged from young adult to late "40s. Deaths occurred in states containing counties with a high or moderate incidence of
Table 1 Demographic and Clinical Data

\begin{tabular}{ll}
\hline Age range, years (median) & Young adult to late 40s (28) \\
Male sex $/ n$ & $4 / 5$ \\
State $(n)$ & NY $(2)$, MA (1), NH (1; exposure \\
& in CT), and IN (1) \\
Month of death $(n)$ & July (4), August (1), November (1) \\
Otherwise healthy $/ n$ & $3 / 5$ \\
Known comorbidities & WPW (1); DM, HBV, and alcohol and \\
& cocaine use (1) \\
Tick exposure activity $/ n$ & $4 / 5$ \\
Prodrome $(n)$ & $<3$ weeks (3), several months (1) \\
Recent joint pain $/ n$ & $3 / 5$ \\
Dermatologic lesion $/ n$ & $0 / 5 ;$ possible spider bite (1) \\
\hline
\end{tabular}

DM, diabetes mellitus; HBV, hepatitis B virus; WPW, Wolf-ParkinsonWhite syndrome.

Lyme disease (New York; New Hampshire, with recent travel to Connecticut; Massachusetts; and Indiana). Deaths occurred in the months of July (three deaths), August (one death), and November (one death) 2012 to 2014. Three patients were otherwise healthy. Two patients had known underlying disease: one patient had a history of WolfParkinson-White syndrome, and another patient had a history of diabetes mellitus, hepatitis $\mathrm{B}$, and cocaine and alcohol use. One patient had given birth approximately 6 months previously. All patients were reported to engage in outdoor activities, two patients had known exposure to ticks, and one patient reported a recent bite.

A prodrome was reported for each of the patients that included the following: nonspecific viral-like illness, malaise, shortness of breath, and anxiety. One of these patients also had joint and muscle pain, and the other two patients had joint pain for an unknown duration. No dermatologic lesion was documented or reported for any of the patients, although one patient was evaluated in an emergency department 1 month before death for an arm lesion diagnosed as a possible spider bite from which methicillin-resistant Staphylococcus aureus was isolated in culture.

One patient underwent pre-mortem serologic screening for Lyme disease and results were negative. Lyme disease was not clinically suspected in a second patient who sought care for episodic shortness of breath; the remaining two patients did not seek medical care. For two cases, Lyme disease initially was suspected by cardiac pathology at a tissue bank transplant service (no cardiac tissue was transplanted). The remaining two patients were diagnosed at the CDC through unexplained-death investigations.

\section{Gross Pathologic Findings}

At autopsy, hearts generally were enlarged (Table 2), one heart was described as diffusely mottled and soft and another heart had an odd muddled coloration with epicardial petechiae, and two patients had significant atherosclerosis. The patient with the smallest heart (380 g; normal, $<350 \mathrm{~g}$ ), who was otherwise healthy, also had the smallest body mass 
Table 2 Pathologic Findings and Borrelia Testing

\begin{tabular}{|c|c|c|}
\hline Parameters assessed & Findings & Normal values \\
\hline \multicolumn{3}{|l|}{ Gross autopsy findings } \\
\hline Heart weight, range (median) & $380-716(650) \mathrm{g}$ & $250-350 \mathrm{~g}$ \\
\hline Heart weight, \% range (median) & $0.45-0.97(0.62)$ & $0.5 \%$ \\
\hline \multirow[t]{5}{*}{ Gross cardiac findings } & Biventricular dilation (1) & \\
\hline & Biventricular dilation and moderate CAD (1) & \\
\hline & Concentric LVH and severe CAD (1) & \\
\hline & Biventricular hypertrophy (1) & \\
\hline & Concentric LVH, biventricular dilatation, and mild CAD (1) & \\
\hline LV thickness, range (median) & $1.4-2.1(1.7) \mathrm{cm}$ & $0.6-1.1 \mathrm{~cm}$ \\
\hline RV thickness, range (median); $n$ & $0.4-1.5(0.5) \mathrm{cm} ; 4$ & $<0.5 \mathrm{~cm}$ \\
\hline Liver weight, range (median) & $1.14-2.55(2.1) \mathrm{kg}$ & $1.4-1.7 \mathrm{~kg}$ \\
\hline Spleen weight, range (median) & $170-440(316) \mathrm{g}$ & $150-200 \mathrm{~g}$ \\
\hline \multicolumn{3}{|l|}{ Microscopic findings } \\
\hline Pancarditis with road map distribution, $n / N$ & $5 / 5$ & \\
\hline Documented conduction system involvement, $n / N$ & $2 / 2$ & \\
\hline Overt cardiomyocyte injury, $n / N$ & $1 / 5$ (focal) & \\
\hline Increased interstitial fibrosis by trichrome, $n / N$ & $5 / 5$ & \\
\hline Cardiac C9 and C4d deposition by IHC, $n / N$ & $0 / 5$ & \\
\hline $\mathrm{T}$ cells $>\mathrm{B}$ cells by $\mathrm{IHC}, n / N$ & $4 / 5$ & \\
\hline \multirow[t]{4}{*}{ Histopathology of other organs $(n / N)$} & Leptomeningitis: mild $(1 / 5)$, minimal $(3 / 5)$ & \\
\hline & Mild portal lymphocytic infiltrates (2/4) & \\
\hline & Cirrhosis $(1 / 4)$ & \\
\hline & Prominent splenic immunoblasts (1) & \\
\hline \multicolumn{3}{|l|}{ Results of Borrelia testing across tissues } \\
\hline Heart-positive WS stain, $n / N$ & $5 / 5$ & \\
\hline Heart-positive Borrelia IHC, $n / N$ & $5 / 5$ & \\
\hline Heart-positive $B$. burgdorferi PCR, $n / N$ & $5 / 5\left(o s p A\right.$ and $f(a A) ; 3 / 5\left(p b p^{*}\right)$ & \\
\hline Other organs positive for Borrelia IHC, $n / N$ & $\begin{array}{l}\text { CNS }(2 / 5) \text {, liver }(0 / 4) \text {, lung }(0 / 5) \text {, kidneys }(0 / 4) \text {, spleen }(0 / 4) \text {, } \\
\text { skin }(0 / 1) \text {, prostate }(0 / 2) \text {, synovium was not available }\end{array}$ & \\
\hline $\begin{array}{l}\text { Other organs and whole blood-positive } \\
\text { B. burgdorferi PCR, } n / N^{\dagger}\end{array}$ & $\begin{array}{l}\text { Liver }(1 / 4) \text {, whole blood }(1 / 1) \text {, CNS }(0 / 5) \text {, lung }(0 / 5) \text {, } \\
\text { kidneys }(0 / 4) \text {, spleen }(0 / 4) \text {, skin }(0 / 1) \text {, synovium } \\
\text { was not available }\end{array}$ & \\
\hline
\end{tabular}

For findings in which $N<5$, not all patient samples were available for testing.

*Sample was positive by $p d p$ PCR, but the positivity was lower than the positive control.

$\dagger$ Other organs tested by ospA PCR; whole blood was tested by flaA and $p d p$ PCR.

CAD, coronary artery disease; CNS, central nervous system; fla, flagellin protein gene; IHC, immunohistochemistry; LV, left ventricle; LVH, left ventricular hypertrophy; ospA, outer surface protein A gene; $p b p$, plasminogen binding protein gene; RV, right ventricle; WS, Warthin-Starry.

$(61 \mathrm{~kg})$, with relative cardiomegaly with a cardiac mass percentage of $0.62 \%$ (normal, $0.5 \%{ }^{44}$ ). The active outdoor enthusiast had a large heart $(570 \mathrm{~g})$, but a $125-\mathrm{kg}$ body mass, for a normal cardiac mass percentage of $0.46 \%$. The patient with a clinical history of Wolf-Parkinson-White syndrome had a $734 \mathrm{~g}$ heart (cardiac mass percentage, $0.74 \%$ ) with $95 \%$ stenosis of the right coronary artery, $90 \%$ stenosis of the left anterior descending coronary artery, and concentric left ventricular hypertrophy. One patient had $60 \%$ stenosis of the left anterior descending coronary artery with biventricular dilation, and another patient had focal mild atherosclerosis with biventricular dilation. Mild hepatosplenomegaly was seen in all cases.

\section{Microscopic Findings}

The cardiac histopathology of these patients was remarkably uniform. At low magnification, a characteristic pattern of intersecting curvilinear bands of interstitial inflammatory infiltrates was observed (Figure 1, A-F), extending from the endocardium to the epicardium. The infiltrate had a prominent perivascular distribution (Figure 1C). No conspicuous differences were appreciated between the infiltrates in the left ventricle, right ventricle, and septum. The conduction system specifically was evaluated in two cases: the atrioventricular and sinoatrial nodes were involved by inflammatory infiltrates in one case, and in another case, sections of the atrioventricular node showed intense necrotizing inflammation (Figure 1D). Coronary arteries were uninvolved by inflammation, although inflammatory infiltrates abutted arterial adventitia in the epicardial adipose tissue. The infiltrates comprised lymphocytes, histiocytes, and prominent plasma cells. Neutrophils and eosinophils were not present in significant numbers, and no multinucleated giant cells, granulomas, or vasculitic changes were seen. Scattered foci of cardiomyocyte contraction band necrosis 

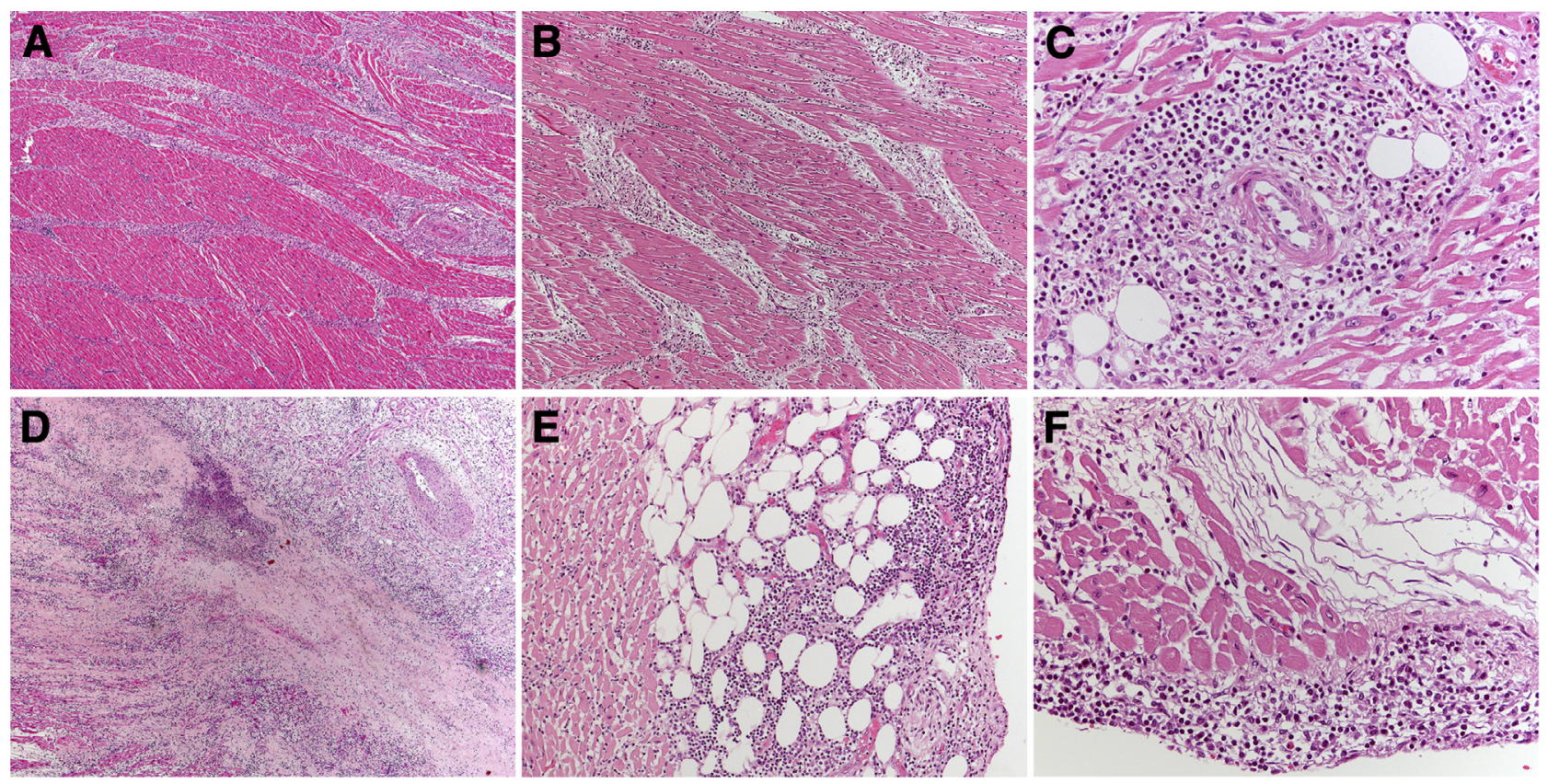

Figure 1 Pathology of Lyme myocarditis. A-C: Carditis with interstitial perivascular lymphoplasmacytic infiltrates in a road map distribution. D: Atrioventricular node. The atrioventricular artery is seen in the upper right. Infiltrates involve epicardial adipose tissue (E) and endocardium $(\mathbf{F})$. Original magnification: $\times 6.25(\mathbf{A}$ and $\mathbf{D}) ; \times 12.5(\mathbf{B}) ; \times 25(\mathbf{E}) ; \times 50(\mathbf{C}$ and $\mathbf{F})$.

were evident in only a single case. Background interstitial fibrosis and cardiomyocyte hypertrophy was noted in one case (the patient with cirrhosis and diabetes).

One case had mild leptomeningeal lymphocytic infiltrates that focally involved cranial nerve roots, in addition to rare parenchymal perivascular infiltrates. Two additional cases had minimal focal leptomeningeal infiltrates. Mild portal lymphocytic infiltrates were present in liver in two cases, and nodular cirrhosis was present in the case with known hepatitis B virus infection. One case had prominent splenic immunoblasts. Sections of lung, kidney, nonlesional skin, and other organs as available (Table 2) showed no significant changes. No joint or synovial tissues were available for analysis.

\section{Histochemical Findings}

By WS stain, spirochetes were seen in the epicardium, myocardium (within bands of interstitial inflammation and fibrosis) (Figure 2A), and endocardium; focally up to approximately 6 per high-power field. One case, after PCR diagnosis, required evaluation of multiple blocks and levels to detect a single convincing spirochete by WS stain. No spirochetes were seen in other tissues by WS stain. Trichrome stains showed increased cardiac interstitial collagen deposition in all cases, particularly in the single case with underlying interstitial fibrosis.

\section{Immunohistochemistry}

By IHC, spirochetes were noted within the myocardial interstitial infiltrates (Figure 2B), in the subendocardium, and occasionally in pericardial tissue in association with lymphohistiocytic infiltrates. No spirochetes were seen within coronary arteries or their branches. Spirochetes were associated with collagen fibers, often apposed along the length of the fibers. Although generally localized in the inflamed interstitium, spirochete density did not appear to have any correlation with the density of inflammatory infiltrates (either within a case or between cases). Compared with WS stain, approximately 5- to 10 -fold more spirochetes were visualized by IHC in sections of cardiac tissue.

Brain was examined in all patients, but only rare spirochetes were seen by IHC in areas of mild inflammation in two of the five cases (Figure 3, A and B). No spirochetes were seen in sections of lung, liver, kidney, spleen, gastrointestinal tract, prostate, or nonlesional skin. Although no joint tissue was available, other soft tissues were examined closely, including fibroadipose and fibroconnective tissue, visceral pleura, splenic and hepatic capsules, and respiratory cartilage.

IHC was negative for cardiomyocyte complement component $\mathrm{C} 4 \mathrm{~d}$ or $\mathrm{C} 9$ in all cases. CD3-positive $\mathrm{T}$ cells outnumbered CD79a-positive B cells in four of the five cases, in an approximate 3:2 ratio; the other case had $\mathrm{T}$ and $\mathrm{B}$ cells in equivalent numbers. Vague nodularity of T-cell and B-cell infiltrates occasionally was observed, but lymphoid follicles were absent in the cardiac inflammatory infiltrates. Immunohistochemical assays for Heartland virus (spleen, $n=3$; lymph node, $n=1$ ) and Powassan virus (central nervous system, $n=5$ ) were negative.

Decorin protein localized to the cardiac interstitium in areas of collagen deposition (Figure 4, A and B). On serial sections performed on all cases, spirochetes co-localized 

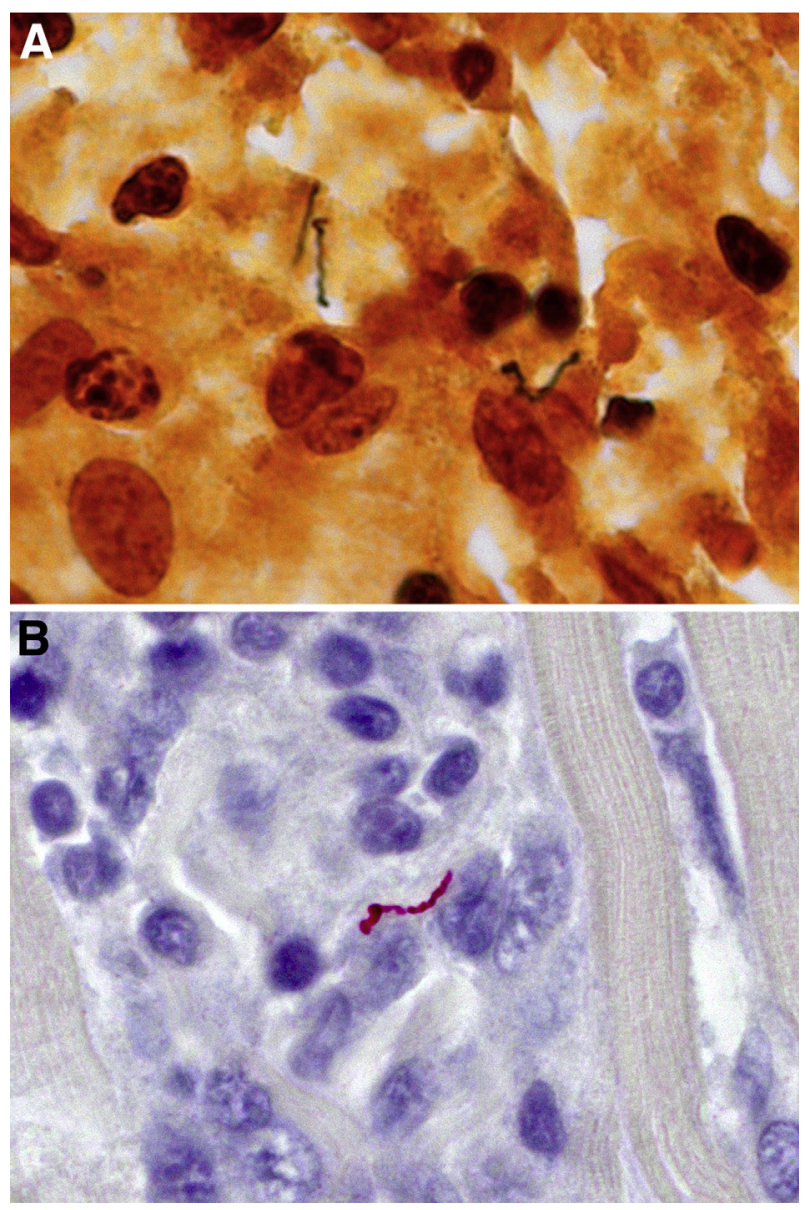

Figure 2 Spirochetes within cardiac tissue. Spirochetes are seen by Warthin-Starry stain (A) and Borrelia species immunohistochemistry (B). Original magnification, $\times 158(\mathbf{A}$ and $\mathbf{B})$.

with collagen fibers and decorin protein (Figure 4, C-E). Decorin immunostaining also was noted in the leptomeninges. Of note, extensive decorin immunostaining also was seen in the collagen-rich prostate interstitium, in addition to splenic and hepatic capsular tissues, in the absence of spirochetes.

\section{Molecular Studies}

Heart tissue was positive for B. burgdorferi by real-time PCR in five of five cases, with one or more of three targets (Table 2). In addition, one available blood sample was positive. The central nervous system was negative by PCR in all cases examined, including from the blocks that had rare spirochetes visualized by IHC. PCR was positive in the liver of one patient. This was the same patient with PCRpositive whole blood who had pre-existing cirrhosis. Multiple sections of this liver specimen subsequently were examined by IHC and remained negative for spirochetes despite extensive evaluation of bands of fibrosis and the hepatic capsule. Molecular testing for B. microti was negative in all patients (heart, $n=4$; spleen, $n=1$ ).

\section{Serology}

Post mortem serum from all five cases tested positive for Lyme disease according to two-tier criteria (Table 3). One sample met both IgM and IgG WB criteria, with two of the three IgM bands and 6 of the $10 \mathrm{IgG}$ bands reactive. The four remaining samples were positive by $\operatorname{IgM}$ WB criteria only, although three were nearly IgG positive with 4 of the 10 bands reactive. Of note, the patient with the positive $\mathrm{IgG}$ was the same patient who had the greatest ratio of B cells to $\mathrm{T}$ cells in the myocardial infiltrates.

\section{Discussion}

Sudden cardiac death associated with Lyme carditis is a rare presentation of a common disease; this study doubles the number of reported cases in the literature. A striking aspect of this case series is that all five patients had remarkably similar clinical and pathologic presentations. The findings support the proposed disease mechanism of spirochete cardiac tropism during early disease dissemination, the infiltration of cardiac tissue by inflammatory cells, and involvement of the conduction system, which likely mediates sudden cardiac death.

Considering these data, a major unanswered question is why sudden cardiac death during Lyme disease is so rare. The pathogenesis likely involves spirochete cardiac tissue tropism, and both host and spirochete factors may contribute to susceptibility. Although it is likely an underdiagnosed entity, underdiagnosis alone does not explain the disease rarity.

Lyme carditis occurs more frequently in men, ${ }^{2,3}$ and four of five sudden cardiac deaths described here, and the previously reported four, occurred in men. Sudden cardiac

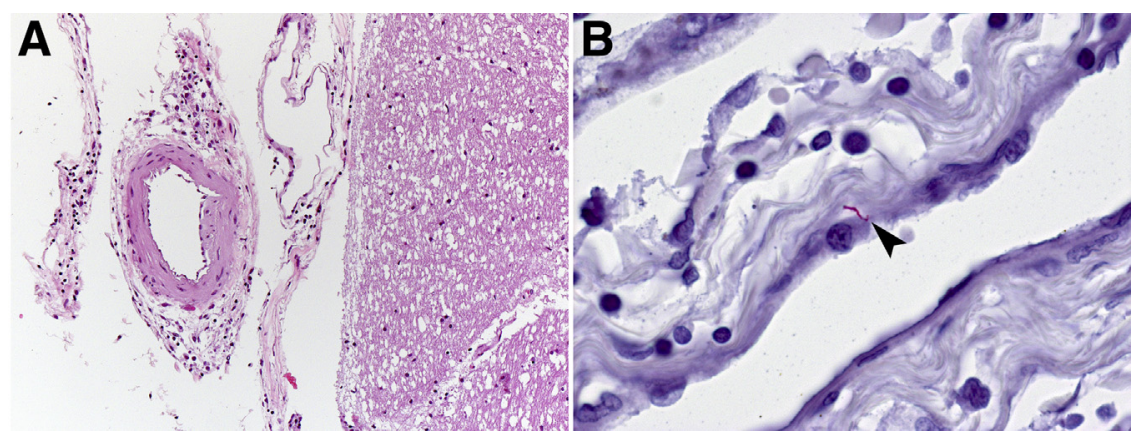

Figure 3 Neuropathology. Brain with mild leptomeningeal lymphocytic infiltrates (A) and rare spirochetes (arrowhead) by Borrelia species immunohistochemistry (B). Original magnification: $\times 25$ (A); $\times 100$ (B). 


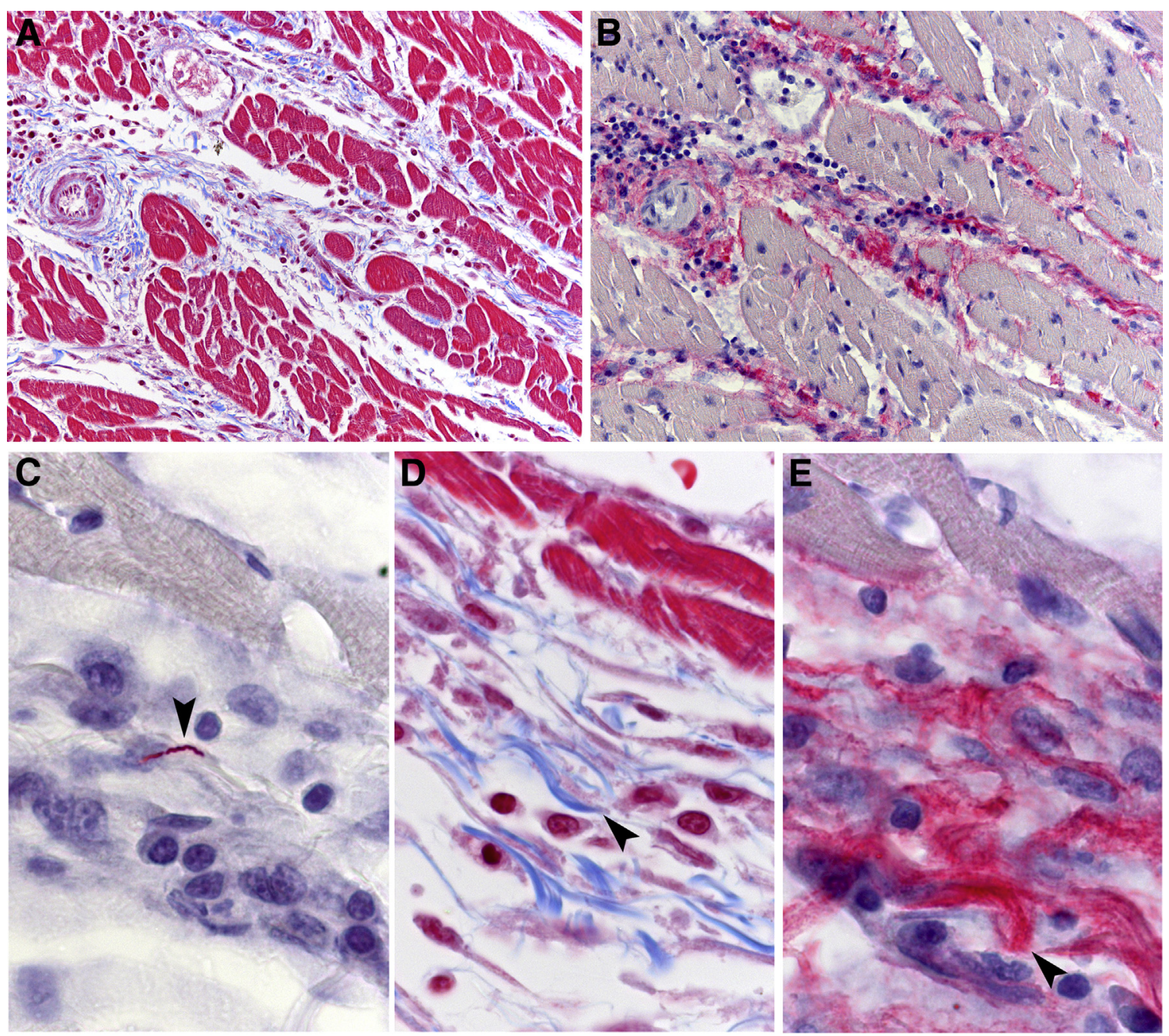

Figure 4 Localization of spirochetes with collagen and decorin. A: Lyme carditis cases show increased interstitial collagen by trichrome stain (blue). B: Cardiac decorin protein is localized to the interstitium by immunohistochemistry (red). C: Spirochetes by immunohistochemistry (IHC) (red, arrowhead) are seen along clear refractile collagen fibers. Collagen fibers are highlighted by decreasing the optical condenser aperture diaphragm (not shown). On consecutive sections, collagen fibers stain blue (arrowhead) by trichrome (D) and label with decorin (red, arrowhead) by IHC (E). Original magnification: $\times 50(\mathbf{A}$ and $\mathbf{B}) ; \times 100(\mathbf{C}, \mathbf{D}$, and $\mathbf{E})$.

death in general occurs more frequently in men, ${ }^{45}$ and WolfParkinson-White syndrome, a cardiac conduction system abnormality present in one of these patients, also is more common in men. A study in Slovenia found that although women present with predominantly cutaneous Lyme disease, men present with noncutaneous disease. ${ }^{46}$ The influence of sex on infectious disease is complex, and may involve differences in hormones, ${ }^{47}$ among other factors including behaviors associated with tick exposure. Of note, all patients also were $<50$ years of age; Lyme carditis has been reported to be more common among men aged 20 to 39 years and women aged 25 to 29 years. $^{2}$

Table 3 Post Mortem Borrelia Serologic Data

\begin{tabular}{llllllll}
\hline Patient & $\begin{array}{l}\text { VIDAS EIA } \\
\text { result }\end{array}$ & VIDAS EIA value* & C6 EIA result & $\begin{array}{l}\text { IgM WB } \\
\text { interpretation }\end{array}$ & $\begin{array}{l}\text { IgM reactive } \\
\text { bands }\end{array}$ & $\begin{array}{l}\text { IgG WB } \\
\text { interpretation }\end{array}$ & $\begin{array}{l}\text { IgG reactive } \\
\text { bands }\end{array}$ \\
\hline 1 & NA & NA & Positive & Positive & $23,39,41$ & Negative & $23,41,58,66$ \\
2 & Positive & 4.74 & Positive & Positive & $23,39,41$ & Negative & 41 \\
3 & Positive & 5.57 & Positive & Positive & $23,39,41$ & Negative & $23,39,41,45$ \\
4 & Positive & 5.86 & Positive & Positive & $23,39,41$ & Negative & $23,41,58,66$ \\
5 & Positive & 5.46 & Positive & Positive & 23,41 & Positive & $23,39,41,45,58,66$ \\
\hline
\end{tabular}

Cut-off values were as follows: negative, $<0.75$; equivocal, $\geq 0.75$ to $<1.00$; and positive, $\geq 1.00$.

*VIDAS Lyme IgM and IgG polyvalent assay by bioMérieux, Inc.

EIA, enzyme immunoassay; NA, not available; VIDAS, Vitek Immunodiagnostic Assay System; WB, Western blot. 
The presence of underlying heart disease might be an additional risk factor for Lyme carditis and/or sudden cardiac death. Significant underlying heart disease was present in two patients, and an additional patient had moderate atherosclerosis discovered at autopsy. In the other two patients, who were otherwise healthy, a degree of physiological cardiac stress likely was present: the woman had given birth 6 months previously and the man was a physically active outdoor enthusiast.

After myocardial injury, cardiac myocytes undergo cell necrosis and are replaced by scar composed of extracellular matrix. ${ }^{48}$ There is a delicate balance between extracellular matrix synthesis and degradation for optimum remodeling of scar tissue to obtain near pre-insult strength. Regulation of the fibroblast and myofibroblast response is performed in part by several extracellular matrix proteins. One of these proteins, decorin, is a ubiquitous proteoglycan associated with type I and type II collagen-rich tissues. ${ }^{49}$ Decorin binds collagen and affects collagen matrix structure and function. ${ }^{50}$ Decorin affects fibroblasts by inhibiting transforming growth factor- $\beta$ signaling, and is down-regulated after initial insult to allow for scar formation. ${ }^{51,52}$ Decorin expression is up-regulated as fibrosis wanes and the physiological remodeling process occurs. In mouse models, decorin is essential for normal fibrotic remodeling after myocardial infarction. ${ }^{53}$ Decorin expression in heart tissue also increases after experimentally increased ventricular afterload in mice, and decreases after physiological remodeling is complete. ${ }^{54}$ In humans, decorin levels are increased markedly in myocardium after placement of left ventricular assist devices prior to transplant. ${ }^{55}$ Although the precise chronology of the decorin increase in human myocardium after insult needs to be elucidated, it is clear that decorin is present in heart tissue during normal physiological remodeling.

B. burgdorferi spirochetes adhere to the extracellular matrix during disseminated infection, and decorin plays a key role. ${ }^{56}$ Decorin binding is mediated by B. burgdorferi decorin binding proteins, in particular decorin binding protein A, which is a $20-\mathrm{kDa}$ surface protein. ${ }^{57}$ The dependence on decorin binding for the spirochete to experimentally infect the heart is striking. Decorin binding protein A is necessary for cardiac localization in a murine model, ${ }^{58}$ and, conversely, cardiac infection is diminished in decorin knock-out mice. ${ }^{59}$ Spirochetes co-localize with decorin in murine myocardium, ${ }^{31}$ as was observed in the autopsy tissues examined here. This case series also showed marked cardiac tropism relative to other organs, as observed in the mouse models. Of note, decorin is expressed in other organs, including lung, liver, kidney, and prostate ${ }^{36,49}$; these visceral organs generally are not involved in Lyme disease, and were negative by Borrelia IHC in this study. The reasons for this are unclear. As a proteoglycan, decorin can have varied glycosaminoglycan chains attached to the protein core ${ }^{60}$ It is possible that cardiacspecific modifications of glycosaminoglycan groups on the decorin protein may alter $B$. burgdorferi spirochete adhesion, as seen with another pathogen, Plasmodium falciparum, in which the placenta-specific sulfation pattern of the chondroitin sulfate A glycosaminoglycan contributes to placental sequestration. ${ }^{61}$

Both spirochete and host genetic factors also may contribute to disease risk. B. burgdorferi genetic variation has been associated with virulence in humans, ${ }^{62}$ and spirochete cardiac localization in mice is influenced by genetic variation in $d b p A .{ }^{33}$ In this study, cultures could not be obtained for typing; future studies may use molecular methods. Little is known of human genetic risk factors for complications of Lyme disease. A Toll-like receptor-1 polymorphism has been associated with antibiotic-refractory Lyme arthritis, ${ }^{63}$ and Toll-like receptor-2-deficient mice had a markedly increased spirochete load in tissues. ${ }^{64}$ On the other hand, genetic associations with cardiac conduction abnormalities are well documented, ${ }^{65}$ and might contribute to risk of conduction abnormality and/or sudden death during Lyme carditis.

Carditis generally is considered a manifestation of early disseminated Lyme disease. Our finding that four of the five patients were seropositive by IgM but not IgG WB criteria is consistent with this view. The greater number of cardiac $T$ cells than $B$ cells seen in the majority of patients might be a feature of the host response during the early disseminated stage of Lyme disease. In early erythema migrans, the dermal infiltrate is predominantly $\mathrm{T}$ cells. ${ }^{66,67} \mathrm{~B}$-cell infiltrates with germinal centers and evidence of pseudoclonality also can be seen later in the disease course, ${ }^{68}$ and can reach high densities, where, particularly in Europe, infections can mimic B-cell lymphoma. ${ }^{69} \mathrm{~B}$ cells also are prominent in arthritis and neuroborreliosis seen in later stages of disease. In mouse models during early infection (1 to 4 weeks after inoculation), myocardial infiltrates comprise T cells and few B cells. ${ }^{70}$ In a nonhuman primate model of Lyme carditis, cardiac plasma cells, tissue $\mathrm{IgG}$, and $\operatorname{IgM}$ deposition, and increased levels of the B-cell chemoattractant chemokine CXCL13 were observed and persisted for months to years after inoculation. ${ }^{71}$ In this case series, the single patient with positive Lyme $\operatorname{IgG}$ serology also had the greatest ratio of cardiac B cells to $T$ cells.

Early diagnosis and prompt treatment for Lyme carditis can be life-saving. Health care professionals should evaluate all patients with suspected Lyme disease for cardiac signs and symptoms, and obtain an electrocardiogram promptly if carditis is suspected. Similarly, providers should consider Lyme disease in patients who have cardiac symptoms and exposure in an endemic area. Diagnosis is based on clinical suspicion and serologic testing, with the caveat that serology testing may be falsely negative in a patient with recent illness onset. ${ }^{72}$ Cardiac biopsies are generally not indicated for the primary diagnosis of Lyme carditis. Information on Lyme disease prevention is available from the CDC (Lyme Disease, http://www.cdc.gov/ lyme, last accessed November 18, 2015). 
The differential diagnosis for acute myocarditis is broad and includes diverse viral, bacterial, and protozoal agents, including enteroviruses and human parvovirus B19, although often no etiologic pathogen can be identified by specialized studies. ${ }^{38}$ Postinfectious, postinflammatory, autoimmune, or drug hypersensitivity phenomena also can cause mycoarditis. The histopathology of the inflammatory infiltrates in Lyme carditis is relatively characteristic. To increase awareness among pathologists and medical examiners, we would like to coin the term "road map" to describe the pattern of intersecting curvilinear bands of interstitial infiltrates seen on low-power magnification. Although this distribution of infiltrates is similar to that seen in hypersensitivity myocarditis, ${ }^{73}$ no granulomas, vasculitis, or significant eosinophilic infiltrates were seen in these Lyme carditis cases. To diagnose Lyme disease in cardiac specimens, the WS stain may be insufficiently sensitive to detect spirochetes and risks false positives owing to high background staining (silver-stained nerve fibers often resemble spirochetes). IHC using a commercially available antibody is a sensitive screening assay, and PCR on FFPE tissues allows for molecular identification and confirmation. Future studies are needed to better understand the incidence of Lyme carditis-associated sudden cardiac death, in addition to investigating mechanisms of spirochete tissue tropism in humans.

\section{Acknowledgments}

We thank the following individuals for their contributions to this investigation: Wayne Daniels (Cryolife, Inc.); Elizabeth R. Daly (New Hampshire Department of Health and Human Services); Catherine M. Brown (Massachusetts Department of Public Health); Randall Nelson and Matthew L. Cartter (Connecticut Department of Public Health); P. Bryon Backenson, Jennifer L. White, Philip M. Kurpiel, and Russell Rockwell (New York State Department of Health); Andrew S. Rotans, Christen Hertzog, and Linda S. Squires (Dutchess County Department of Health); Jeanne V. Linden and Susan J. Wong (New York State Department of Health); Jennifer House and Pam Pontones (Indiana State Department of Health); and Alison Hinckley, Christina Nelson, Amy Denison, Jeltley Montague, and Tara Jones (CDC).

\section{References}

1. Hinckley AF, Connally NP, Meek JI, Johnson BJ, Kemperman MM, Feldman KA, White JL, Mead PS: Lyme disease testing by large commercial laboratories in the United States. Clin Infect Dis 2014, 59:676-681

2. Forrester JD, Meiman J, Mullins J, Nelson R, Ertel SH, Cartter M, et al; Centers for Disease Control and Prevention: Notes from the field: update on Lyme carditis, groups at high risk, and frequency of associated sudden cardiac death-United States. MMWR Morb Mortal Wkly Rep 2014, 63:982-983

3. Forrester JD, Mead P: Third-degree heart block associated with lyme carditis: review of published cases. Clin Infect Dis 2014, 59: 996-1000

4. Fish AE, Pride YB, Pinto DS: Lyme carditis. Infect Dis Clin North Am 2008, 22:275-288. vi

5. Wormser GP, Dattwyler RJ, Shapiro ED, Halperin JJ, Steere AC, Klempner MS, Krause PJ, Bakken JS, Strle F, Stanek G, Bockenstedt L, Fish D, Dumler JS, Nadelman RB: The clinical assessment, treatment, and prevention of lyme disease, human granulocytic anaplasmosis, and babesiosis: clinical practice guidelines by the Infectious Diseases Society of America. Clin Infect Dis 2006, 43: 1089-1134

6. Cary NR, Fox B, Wright DJ, Cutler SJ, Shapiro LM, Grace AA: Fatal Lyme carditis and endodermal heterotopia of the atrioventricular node. Postgrad Med J 1990, 66:134-136

7. Marcus LC, Steere AC, Duray PH, Anderson AE, Mahoney EB: Fatal pancarditis in a patient with coexistent Lyme disease and babesiosis. Demonstration of spirochetes in the myocardium. Ann Intern Med 1985, 103:374-376

8. Tavora F, Burke A, Li L, Franks TJ, Virmani R: Postmortem confirmation of Lyme carditis with polymerase chain reaction. Cardiovasc Pathol 2008, 17:103-107

9. Reimers CD, de Koning J, Neubert U, Preac-Mursic V, Koster JG, Muller-Felber W, Pongratz DE, Duray PH: Borrelia burgdorferi myositis: report of eight patients. J Neurol 1993, 240:278-283

10. Centers for Disease Control and Prevention: Three sudden cardiac deaths associated with Lyme carditis - United States, November 2012-July 2013. MMWR Morb Mortal Wkly Rep 2013, 62: 993-996

11. Duray PH: The surgical pathology of human Lyme disease. An enlarging picture. Am J Surg Pathol 1987, 11 Suppl 1:47-60

12. Duray PH, Steere AC: Clinical pathologic correlations of Lyme disease by stage. Ann N Y Acad Sci 1988, 539:65-79

13. Johnston YE, Duray PH, Steere AC, Kashgarian M, Buza J, Malawista SE, Askenase PW: Lyme arthritis. Spirochetes found in synovial microangiopathic lesions. Am J Pathol 1985, 118: 26-34

14. Duray PH: Clinical pathologic correlations of Lyme disease. Rey Infect Dis 1989, 11(Suppl 6):S1487-S1493

15. de Koning J, Hoogkamp-Korstanje JA, van der Linde MR, Crijns HJ: Demonstration of spirochetes in cardiac biopsies of patients with Lyme disease. J Infect Dis 1989, 160:150-153

16. Bertrand E, Szpak GM, Pilkowska E, Habib N, LipczynskaLojkowska W, Rudnicka A, Tylewska-Wierzbanowska S, Kulczycki J: Central nervous system infection caused by Borrelia burgdorferi. Clinico-pathological correlation of three post-mortem cases. Folia Neuropathol 1999, 37:43-51

17. Miklossy J, Kuntzer T, Bogousslavsky J, Regli F, Janzer RC: Meningovascular form of neuroborreliosis: similarities between neuropathological findings in a case of Lyme disease and those occurring in tertiary neurosyphilis. Acta Neuropathol 1990, 80: $568-572$

18. Meurers B, Kohlhepp W, Gold R, Rohrbach E, Mertens HG: Histopathological findings in the central and peripheral nervous systems in neuroborreliosis. A report of three cases. J Neurol 1990, 237: $113-116$

19. Kirsch M, Ruben FL, Steere AC, Duray PH, Norden CW, Winkelstein A: Fatal adult respiratory distress syndrome in a patient with Lyme disease. JAMA 1988, 259:2737-2739

20. Schlesinger PA, Duray PH, Burke BA, Steere AC, Stillman MT: Maternal-fetal transmission of the Lyme disease spirochete, Borrelia burgdorferi. Ann Intern Med 1985, 103:67-68

21. MacDonald AB: Gestational Lyme borreliosis. Implications for the fetus. Rheum Dis Clin North Am 1989, 15:657-677 
22. Berger BW: Erythema chronicum migrans of Lyme disease. Arch Dermatol 1984, 120:1017-1021

23. Berger BW, Kaplan MH, Rothenberg IR, Barbour AG: Isolation and characterization of the Lyme disease spirochete from the skin of patients with erythema chronicum migrans. J Am Acad Dermatol 1985, 13:444-449

24. Van Mierlo P, Jacob W, Dockx P: Erythema chronicum migrans: an electron-microscopic study. Dermatology 1993, 186:306-310

25. Haupl T, Hahn G, Rittig M, Krause A, Schoerner C, Schonherr U, Kalden JR, Burmester GR: Persistence of Borrelia burgdorferi in ligamentous tissue from a patient with chronic Lyme borreliosis. Arthritis Rheum 1993, 36:1621-1626

26. Cimmino MA, Azzolini A, Tobia F, Pesce CM: Spirochetes in the spleen of a patient with chronic Lyme disease. Am J Clin Pathol 1989, 91:95-97

27. Rank EL, Dias SM, Hasson J, Duray PH, Johnson RC, Magnarelli LA, Fister RD: Human necrotizing splenitis caused by Borrelia burgdorferi. Am J Clin Pathol 1989, 91:493-498

28. Hajjar RJ, Kradin RL: Case records of the Massachusetts General Hospital. Weekly clinicopathological exercises. Case 17-2002. A 55year-old man with second-degree atrioventricular block and chest pain. N Engl J Med 2002, 346:1732-1738

29. Colli C, Leinweber B, Mullegger R, Chott A, Kerl H, Cerroni L: Borrelia burgdorferi-associated lymphocytoma cutis: clinicopathologic, immunophenotypic, and molecular study of 106 cases. J Cutan Pathol 2004, 31:232-240

30. Eisendle K, Grabner T, Zelger B: Focus floating microscopy: "gold standard" for cutaneous borreliosis? Am J Clin Pathol 2007, 127 : 213-222

31. Imai DM, Feng S, Hodzic E, Barthold SW: Dynamics of connectivetissue localization during chronic Borrelia burgdorferi infection. Lab Invest 2013, 93:900-910

32. Brissette CA, Gaultney RA: That's my story, and I'm sticking to it-an update on B. burgdorferi adhesins. Front Cell Infect Microbiol 2014, 4:41

33. Lin YP, Benoit V, Yang X, Martinez-Herranz R, Pal U, Leong JM: Strain-specific variation of the decorin-binding adhesin DbpA influences the tissue tropism of the lyme disease spirochete. PLoS Pathog 2014, 10:e1004238

34. Jenkins CP, Cardona DM, Bowers JN, Oliai BR, Allan RW, Normann SJ: The utility of C4d, C9, and troponin T immunohistochemistry in acute myocardial infarction. Arch Pathol Lab Med 2010, 134:256-263

35. Paddock CD, Liu L, Denison AM, Bartlett JH, Holman RC, DeleonCarnes M, Emery SL, Drew CP, Shieh WJ, Uyeki TM, Zaki SR: Myocardial injury and bacterial pneumonia contribute to the pathogenesis of fatal influenza B virus infection. J Infect Dis 2012, 205:895-905

36. Henke A, Grace OC, Ashley GR, Stewart GD, Riddick AC, Yeun H, O'Donnell M, Anderson RA, Thomson AA: Stromal expression of decorin, Semaphorin6D, SPARC, Sprouty1 and Tsukushi in developing prostate and decreased levels of decorin in prostate cancer. PLoS One 2012, 7:e42516

37. Muehlenbachs A, Fata CR, Lambert AJ, Paddock CD, Velez JO, Blau DM, Staples JE, Karlekar MB, Bhatnagar J, Nasci RS, Zaki SR: Heartland virus-associated death in tennessee. Clin Infect Dis 2014, $59: 845-850$

38. Guarner J, Bhatnagar J, Shieh WJ, Nolte KB, Klein D, Gookin MS, Penaranda S, Oberste MS, Jones T, Smith C, Pallansch MA, Zaki SR: Histopathologic, immunohistochemical, and polymerase chain reaction assays in the study of cases with fatal sporadic myocarditis. Hum Pathol 2007, 38:1412-1419

39. Straubinger RK: PCR-Based quantification of Borrelia burgdorferi organisms in canine tissues over a 500-Day postinfection period. J Clin Microbiol 2000, 38:2191-2199

40. Pahl A, Kuhlbrandt U, Brune K, Rollinghoff M, Gessner A: Quantitative detection of Borrelia burgdorferi by real-time PCR. J Clin Microbiol 1999, 37:1958-1963
41. Babady NE, Sloan LM, Vetter EA, Patel R, Binnicker MJ: Percent positive rate of Lyme real-time polymerase chain reaction in blood, cerebrospinal fluid, synovial fluid, and tissue. Diagn Microbiol Infect Dis 2008, 62:464-466

42. Froberg MK, Dannen D, Bernier N, Shieh WJ, Guarner J, Zaki S: Case report: spontaneous splenic rupture during acute parasitemia of Babesia microti. Ann Clin Lab Sci 2008, 38:390-392

43. Centers for Disease Control and Prevention: Recommendations for test performance and interpretation from the Second National Conference on Serologic Diagnosis of Lyme Disease. MMWR Morb Mortal Wkly Rep 1995, 44:590-591

44. Gaitskell K, Perera R, Soilleux EJ: Derivation of new reference tables for human heart weights in light of increasing body mass index. J Clin Pathol 2011, 64:358-362

45. Deo R, Albert CM: Epidemiology and genetics of sudden cardiac death. Circulation 2012, 125:620-637

46. Strle F, Wormser GP, Mead P, Dhaduvai K, Longo MV, Adenikinju O, Soman S, Tefera Y, Maraspin V, Lotric-Furlan S, Ogrinc K, Cimperman J, Ruzic-Sabljic E, Stupica D: Gender disparity between cutaneous and non-cutaneous manifestations of Lyme borreliosis. PLoS One 2013, 8:e64110

47. Leone M, Honstettre A, Lepidi H, Capo C, Bayard F, Raoult D, Mege JL: Effect of sex on Coxiella burnetii infection: protective role of 17beta-estradiol. J Infect Dis 2004, 189:339-345

48. Jourdan-Lesaux C, Zhang J, Lindsey ML: Extracellular matrix roles during cardiac repair. Life Sci 2010, 87:391-400

49. Bianco P, Fisher LW, Young MF, Termine JD, Robey PG: Expression and localization of the two small proteoglycans biglycan and decorin in developing human skeletal and non-skeletal tissues. J Histochem Cytochem 1990, 38:1549-1563

50. Kalamajski S, Oldberg A: The role of small leucine-rich proteoglycans in collagen fibrillogenesis. Matrix Biol 2010, 29:248-253

51. Costacurta A, Priante G, D'Angelo A, Chieco-Bianchi L, Cantaro S: Decorin transfection in human mesangial cells downregulates genes playing a role in the progression of fibrosis. J Clin Lab Anal 2002, 16 : $178-186$

52. Khan R, Sheppard R: Fibrosis in heart disease: understanding the role of transforming growth factor-beta in cardiomyopathy, valvular disease and arrhythmia. Immunology 2006, 118:10-24

53. Hao J, Ju H, Zhao S, Junaid A, Scammell-La Fleur T, Dixon IM: Elevation of expression of Smads 2, 3, and 4, decorin and TGF-beta in the chronic phase of myocardial infarct scar healing. J Mol Cell Cardiol 1999, 31:667-678

54. Engebretsen KV, Waehre A, Bjornstad JL, Skrbic B, Sjaastad I, Behmen D, Marstein HS, Yndestad A, Aukrust P, Christensen G, Tonnessen T: Decorin, lumican, and their GAG chain-synthesizing enzymes are regulated in myocardial remodeling and reverse remodeling in the mouse. J Appl Physiol 2013, 114:988-997

55. Jahanyar J, Joyce DL, Southard RE, Loebe M, Noon GP, Koerner MM, Torre-Amione G, Youker KA: Decorin-mediated transforming growth factor-beta inhibition ameliorates adverse cardiac remodeling. J Heart Lung Transplant 2007, 26:34-40

56. Guo BP, Norris SJ, Rosenberg LC, Hook M: Adherence of Borrelia burgdorferi to the proteoglycan decorin. Infect Immun 1995, 63: $3467-3472$

57. Fischer JR, Parveen N, Magoun L, Leong JM: Decorin-binding proteins $\mathrm{A}$ and $\mathrm{B}$ confer distinct mammalian cell type-specific attachment by Borrelia burgdorferi, the Lyme disease spirochete. Proc Natl Acad Sci U S A 2003, 100:7307-7312

58. Shi Y, Xu Q, McShan K, Liang FT: Both decorin-binding proteins A and $\mathrm{B}$ are critical for the overall virulence of Borrelia burgdorferi. Infect Immun 2008, 76:1239-1246

59. Brown EL, Wooten RM, Johnson BJ, Iozzo RV, Smith A, Dolan MC, Guo BP, Weis JJ, Hook M: Resistance to Lyme disease in decorindeficient mice. J Clin Invest 2001, 107:845-852

60. Skandalis SS, Kletsas D, Kyriakopoulou D, Stavropoulos M, Theocharis DA: The greatly increased amounts of accumulated 
versican and decorin with specific post-translational modifications may be closely associated with the malignant phenotype of pancreatic cancer. Biochim Biophys Acta 2006, 1760: $1217-1225$

61. Achur RN, Valiyaveettil M, Gowda DC: The low sulfated chondroitin sulfate proteoglycans of human placenta have sulfate group-clustered domains that can efficiently bind Plasmodium falciparum-infected erythrocytes. J Biol Chem 2003, 278: 11705-11713

62. Strle K, Jones KL, Drouin EE, Li X, Steere AC: Borrelia burgdorferi RST1 (OspC type A) genotype is associated with greater inflammation and more severe Lyme disease. Am J Pathol 2011, 178: $2726-2739$

63. Strle K, Shin JJ, Glickstein LJ, Steere AC: Association of a Toll-like receptor 1 polymorphism with heightened Th1 inflammatory responses and antibiotic-refractory Lyme arthritis. Arthritis Rheum 2012, 64:1497-1507

64. Wooten RM, Ma Y, Yoder RA, Brown JP, Weis JH, Zachary JF, Kirschning CJ, Weis JJ: Toll-like receptor 2 is required for innate, but not acquired, host defense to Borrelia burgdorferi. J Immunol 2002, 168:348-355

65. Perez MV, Wheeler M, Ho M, Pavlovic A, Wang P, Ashley EA: Genetics of arrhythmia: disease pathways beyond ion channels. J Cardiovasc Transl Res 2008, 1:155-165

66. Buchner SA, Rufli T: Erythema chronicum migrans: evidence for cellular immune reaction in the skin lesion. Dermatologica 1987, 174: $144-149$
67. Salazar JC, Pope CD, Sellati TJ, Feder HM Jr, Kiely TG, Dardick KR, Buckman RL, Moore MW, Caimano MJ, Pope JG, Krause PJ, Radolf JD; Lyme Disease Network: Coevolution of markers of innate and adaptive immunity in skin and peripheral blood of patients with erythema migrans. J Immunol 2003, 171:2660-2670

68. Boer A, Bresch M, Dayrit J, Falk TM: Erythema migrans: a reassessment of diagnostic criteria for early cutaneous manifestations of borreliosis with particular emphasis on clonality investigations. Br J Dermatol 2007, 156:1263-1271

69. Grange F, Wechsler J, Guillaume JC, Tortel J, Tortel MC, Audhuy B, Jaulhac B, Cerroni L: Borrelia burgdorferi-associated lymphocytoma cutis simulating a primary cutaneous large B-cell lymphoma. J Am Acad Dermatol 2002, 47:530-534

70. Ruderman EM, Kerr JS, Telford SR 3rd, Spielman A, Glimcher LH, Gravallese EM: Early murine Lyme carditis has a macrophage predominance and is independent of major histocompatibility complex class II-CD4+ T cell interactions. J Infect Dis 1995, 171:362-370

71. Cadavid D, Bai Y, Hodzic E, Narayan K, Barthold SW, Pachner AR: Cardiac involvement in non-human primates infected with the Lyme disease spirochete Borrelia burgdorferi. Lab Invest 2004, 84: 1439-1450

72. Johnson BJ: Laboratory diagnostic testing for Borrelia burgdorferi infection. Edited by Halperin JJ. Lyme disease an evidence based approach. Wallingford, Oxfordshire, UK: CABI, 2011, pp 73-88

73. Burke AP, Saenger J, Mullick F, Virmani R: Hypersensitivity myocarditis. Arch Pathol Lab Med 1991, 115:764-769 